\section{2lcta 3 iologica Sibirica}

Journal of Biology

Founded in 2015
Altai State University

www.asu.ru

ISSN 2412-1908

\title{
First record of Argynnis pandora ([Denis \& Schiffermüller], 1775) (Lepidoptera, Nymphalidae) on the Northern Altai (Russia, Southern Siberia)
}

\author{
S.A. Knyazev \\ Russian Entomological Society, Omsk, Russia, e-mail: konungomsk@yandex.ru \\ Altai State University, Lenina 61, Barnaul, 656049, Russia
}

The first record of Argynnis pandora ([Denis \& Schiffermüller], 1775) reported from the Northern part of the Republic of Altai.

Key words: Altai, Southern Siberia, rare species, Nymphalidae.

\section{Первая находка Argynnis pandora ([Denis \& Schiffermüller], 1775) (Lepidoptera, Nymphalidae) на Северном Алтае (Россия, Южная Сибирь)}

\author{
С.А. Князев \\ Русское энтомологическое общество, Омск, Россия, e-mail: konungomsk@yandex.ru \\ Алтайский государственный университет, Ленина, 61, Барнаул, 656049, Россия
}

В статье сообщается о первой встрече перламутровки Argynnis pandora ([Denis \& Schiffermüller], 1775) на севере Республики Алтай

Ключевые слова: Республика Алтай, Южная Сибирь, редкий вид, Nymphalidae.

Argynnis pandora ([Denis \& Schiffermüller], 1775) - широко распространенный в Западной Палеарктике вид. Ареал охватывает Северную Африку, Южную Европу, Среднюю, Центральную и Южную Азию, Казахстан. В России вид обитает на юге европейской части, единично отмечался на Южном Урале (Korshunov, 2002). Первая встреча вида в Горном Алтае была зафиксирована в августе 2009 г. в Курайской степи, в долине р. Кызыл-Taш (Tshikolovets et al., 2009). 5 августа 2017 г. автором была встречена самка перламутровки пандоры в 190 км СВ от известного ранее локалитета, в 2 км восточнее с. Чемал (51²2'45.8"N 8604'54.6"Е). Бабочка обнаружена на лесной поляне в сосновом бору, летающей над цветущим разнотравьем, в сообществе с другими крупными перламутровками Argynnis paphia (Linnaeus, 1758) и Argynnis sagana Doubleday, [1847]. Собранный экземпляр хранится в коллекции сборщика. К настоящему времени данная точка является самой северо-восточной в ареале вида. Учитывая высокие лётные способности вида и склонность к расселению, вполне ожидаемы дальнейшие встречи перламутровки пандоры в прилегающих регионах (Алтайский край, Кемеровская область, Хакасия, Тува). 
Knyazev, S.A. First record of Argynnis pandora.... Acta Biologica Sibirica, 2018, 4(2), 78-79

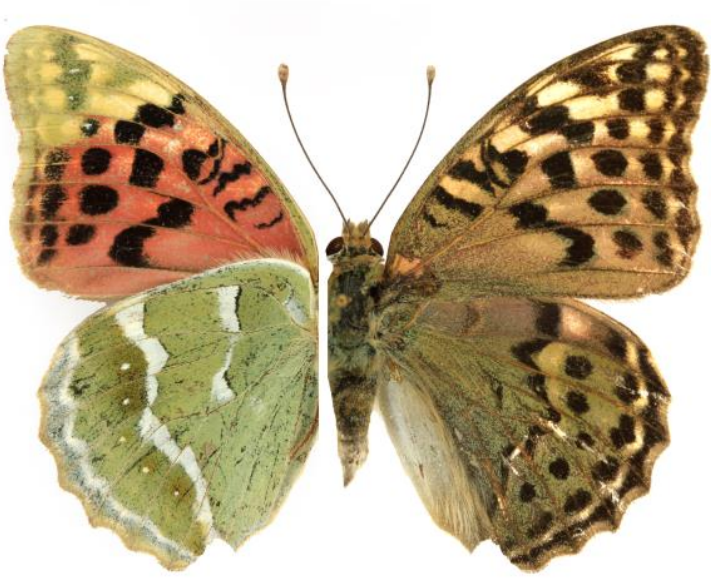

Рис. 1. Argynnis pandora ([Denis \& Schiffermüller], 1775), самка, общий вид, республика Алтай, Чемальский р-н, 2 км. В с. Чемал, 5.VIII.2017 (C.A. Князев)

\section{References}

Korshunov, Yu.P. (2002). Bulavousyie cheshuekrylyie Severnoi Aziyi. M.: KMK-Press. (in Russian)

Tshikolovets, V.V., Yakovlev, R.V., Kosterin, O.E. (2009). The Butterflies of Altai, Sayans and Tuva (South Siberia). KyivPardubice: Tshikolovets-press.

\section{Citation:}

Knyazev, S.A. (2018). First record of Argynnis pandora ([Denis \& Schiffermüller], 1775) (Lepidoptera, Nymphalidae) on the Northern Altai (Russia, Southern Siberia). Acta Biologica Sibirica, 4 (2), 78-79.

Submitted: 09.02.2018. Accepted: 13.03.2018

cross ref http://dx.doi.org/10.14258/abs.v4i2.4126

(C) 2018 by the authors. Submitted for possible open access publication under the terms and conditions of the Creative Commons Attribution (CC BY) license (http://creativecommons.org/licenses/by/4.0/). 